\title{
ОСОБЛИВОСТІ ПУБЛІЧНИХ ЗАКУПІВЕЛЬ В УКРАЇНІ В КОНТЕКСТІ ЄВРОІНТЕГРАЦІї
}

\section{PECULIARITIES OF PUBLIC PROCUREMENT DEVELOPMENT IN UKRAINE IN THE CONTEXT OF EUROPEAN INTEGRATION}

УДК 336.13

https://doi.org/10.32843/bses.65-16

\section{Юрій E.O.}

к.е.н., доцент,

завідувач кафедри публічних, корпоративних фрінансів

та фрінансового посередництва

Чернівецький національний університет

імені Юрія Федьковича

Юзюк В.М.

магістрант

Чернівецький національний університет імені Юрія Федьковича

\section{Yurii Eduard}

Yurii Fedkovych Chernivtsi

National University

Yuziuk Viktoriia

Yuriy Fedkovych Chernivtsi

National University

\begin{abstract}
у статmі досліджено особливості здійснення публічних закупівель в Україні та їх відповідність нормативам ЄС, чинники, які впливають на їх ефективність. Розглянуто проблеми тендерних закупівель, які існують в Україні при проведенні. Оцінено зміни, які відбулися у здійсненні закупівель після запровадження в 2020 р. нової редакціі Закону України «Про публічні закупівлі». Надано детальну характеристику досвіду Польщі у проведенні публічних закупівель. Проаналізовано кількість та види договорів, які були укладені під час закупівель. Розглянуто основні існуючі недоліки у сфрері публічних закупівель, шляхи їх вирішення та вдосконалення. Визначено ключові правила ЄС щодо державних закупівель, які повинні бути використані в Україні. Встановлено, що важливим $\epsilon$ наблизити механізм здійснення публічних закупівель в Україні до вимог ЄС, що дозволить нашій країні в майбутньому ставити питання щодо вступу в цю організацію.

Ключові слова: публічні фрінанси, тендерні закупівлі, Європейський Союз, Польща.
\end{abstract}

В статье исследованы особенности осуществления публичных закупок в Украине и их соответствие нормативам ЕC, фракторы, влияющие на их эфффективность. Рассмотрены проблемы тендерных закупок, которые существуют в Украине при проведении. Оценены изменения, которые произошли в осуществлении закупок после введения в 2020 г. Новой редакции Закона Украины «О публичных закупках». Предоставлено подробную характеристику опыта Польши в проведении публичных закупок. Проанализированы количество и виды договоров, которые были заключены при закупках. Рассмотрены основные существующие недостатки в сорере публичных закупок, пути их решения и совершенствования. Определены ключевые правила EC о государственных закупках, которые должны быть использованы в Украине. Установлено, что важно приблизить механизм осуществления публичных закупок в Украине с требованиями EC, что позволит нашей стране в будущем ставить вопрос о вступлении в эту организацию.

Ключевые слова: публичные фринансы, тендерные закупки, Европейский Союз, Польша.

The article examines the features of public procurement in Ukraine and their compliance with EU standards, the factors that affect their effectiveness. The problems of tender purchases that exist in Ukraine during the process are considered. The changes that took place in the implementation of procurement after the introduction in 2020 of a new version of the Law of Ukraine "On Public Procurement" are assessed. A detailed description of Poland's experience in public procurement is provided. The number and types of contracts concluded during procurement are analyzed. The main existing shortcomings in the field of public procurement, ways to solve and improve them are considered. The key EU rules on public procurement to be used in Ukraine have been identified. It was established that it is important to bring the mechanism of public procurement in Ukraine closer to the EU requirements, which will allow our country to raise the issue of joining this organization in the future. The purpose of the article is to analyze the features and problems of public procurement in Ukraine and find ways to overcome them. The main task of reforming the sphere of public finances in our country is to introduce an effective mechanism for the use of public procurement in accordance with the principles and approaches applied by EU countries, which should ensure financial efficiency and transparency of the procurement procedure. Public procurement is one of the tools to regulate supply and demand for specific publications. To increase the transparency and efficiency of use in our country, it is necessary to study the experience of EU member states, especially Poland. Analysis of the experience of public procurement in the $E U$ will be able to identify effective approaches to their implementation in Ukraine, thanks to the main tasks of public procurement reform in our country will introduce an effective system in accordance with the principles and approaches used by EU countries. It is necessary to investigate the change that has taken place in public procurement after the introduction in 2020 of a new version of the Law of Ukraine "On Public Procurement", there are both positive and negative aspects that are due to the existence of corruption schemes in tenders.

Key words: public finance, tender procurement, European Union, Poland.

Постановка проблеми. у системі публічних фрінансів України зростає роль і значення публічних закупівель, які вже перетворилися на найбільший ринок країни. Важливо добитися ефрективного використання публічних коштів, виділених на публічні закупівлі в Україні, чого поки не відбувається.

Аналіз останніх джерел і публікацій. 3 кожним роком все більше вчених і практиків шукають підходи до вирішення проблем підвищення фрінансової ефрективності публічних закупівель. Основні аспекти публічних закупівель у країнах світу та в Україні дослідили такі зарубіжні і українські вчені, як: Г. Азаренкова, А. Бойер, А. Буряченко, В. Виговська, В. Геєць, Д. Гелбрейт, Т. Жибер, Д. Кауф- ман, Н. Конащук, М. Крупка, І. Луніна, О. Мельник, В. Міняйло, В. Смирчинський, І. Стефранюк, Дж. Стігліц, Н. Ткаченко, Ю. Фалко, В. Федосов, Г. Харченко, А. Хайнеман, А. Храмкін, В. Чабан, I. Чорна, І. Чугунов, Р. Шаппер та інші. Проаналізувавши досвід проведення державних закупівель в країнах ЄС можна виявити ефективні підходи до їх здійснення й в Україні.

Постановка завдання. Основним завданням рефрормування сорери публічних фрінансів у нашій країні $€$ впровадження ефрективного механізму використання публічних закупівель відповідно до принципів і підходів, які застосовуються країнами $€ C$, що має забезпечити фрінансову ефективність та прозорість процедури закупівель. 
Викладення основного матеріалу дослідження. Для проведення тендерних закупівель в Україні потрібно дотримуватись норм і правил, які зафріксовані в Угоді нашої країни про асоціацію з ЄС, але поки що цього не вдається досягнути. Також, для ефективної і належної роботи використання публічних фрінансів, необхідно забезпечити підвищення відповідальності всіх їх учасників. Потрібно враховувати і той оракт, що щорічний обсяг публічних закупівель в Україні наразі перевищує 600 млрд. грн.

щоб наблизити механізм до норм ЄС, важливо не допускати порушень тендерних закупівель, поки цього не вистачає в Україні, але деякі позитивні зміни в цьому процесі вже відбуваються. Позитивною зміною в публічних закупівлях в Україні $€$ те, що вони проводяться в онлайн режимі, учасникам надається спрощений пакет документів для участі в тендерних закупівлях, присутня відкритість даних про оголошені закупівлі та виконані договори тощо.

Міжнародна практика тендерних торгів показує, що можна економити від 10 до 20\% запланованих коштів саме на закупівлю при використанні конкурентних механізмів, також, дозволяє зробити процедуру витрат коштів гласною і відкритою, підвищуючи довіру громадськості до державного сектору [2, с. 72].

У цій сорері найбільших успіхів досягнули Данія, Канада, Ірландія, Австралія, Норвегія, Мексика, Швеція. За останні роки система електронних торгів здобула широкого розповсюдження й у деяких країнах пострадянського простору - Росії, Білорусі, Казахстані, Грузії.

В законодавстві України вносять вже певні зміни, але Україна поки не реалізувала вимоги міжнародних організацій до прозорого здійснення публічних закупівель та подолання корупції при їх проведенні. Антимонопольним комітетом України (АМКУ) в кінці 2019 року було розкрито змову у п'яти торгах, які проводились Укрзалізницею, накладені на учасників штрафи становили 60,8 млн. грн. Так, дві компанії брали участь у чотирьох торгах на закупівлю запасних частин в пасажирські вагони, вікон, ящиків, що призвело до узгодженості їх дій та до викривлення результатів торгів. Це призвело до накладення на них штрафру в розмірі 55 млн. грн. Ці та подібні випадки ускладнюють отримання нашою країною необхідних кредитів та допомог від МВФ, Євросоюзу, інших міжнародних організацій.

Необхідно добиватися максимальної ефективності від їх проведення, мінімізуючи існуючі недоліки. До останніх недоліків можна віднести [5, с. 1]: корупція, недосконале правове регулювання кваліфрікаційного відбору постачальників, дещо низький профресійний рівень державних замовників, приділення невеликої уваги фрінансовій спромож- ності позичальників, основна перевага критерію ціни при виборі переможця торгів, тривала процедура проведення тендерів, недостатнє забезпечення офрісною технікою та мережею Інтернет для роботи саме з системою «Прозорро». Також на посадову особу бюджетної організації покладаються обов'язки з проведення публічних закупівель, а це великий та відповідальний обсяг роботи, і не всі державні установи мають можливість оплатити навчання своїм спеціалістам.

Тому в Україні необхідно максимально використати досвід країн ЄС у проведенні публічних закупівель, передусім досвід Польщі [4].

У Польщі 32004 року закупівлі регулюються Законом «Про публічні закупівлі», в цьому році Польща вступила до ЄС. Останні зміни у Закон внесені у 2016 році, в ньому визначаються загальні норми публічних закупівель, фрункції та роль Агентства публічних замовлень.

Закон поширюється на публічні закупівлі, які перевищують 30 тисяч євро. Встановлюються межі для обов'язкового проведення міжнародних тендерів, 418 тис. євро - товари і послуги та 5 млн. 225 тис. євро для робіт.

Державні органи та установи і організації, що фрінансуються з бюджету Польщі і підприємства, що діють в окремих секторах є суб'єктами, на які поширюється дія Закону.

Польське Агентство публічних замовлень здійснює як моніторинг дотримання вимог закону у процедурах закупівлі, так і макромоніторинг функціонування всієї системи державних закупівель Польщі, на що Українському уряду доцільно звернути особливу увагу [1]. Підлягають обов'язковому контролю закупівлі, що фрінансуються чи співфрінансуються за рахунок коштів ЄС, що дорівнюють чи перевищують 10 млн. євро (при закупівлі товарів чи послуг) та 20 млн. євро (для робіт).

Українському уряду необхідно звернути увагу саме на здійснення аналітичного моніторингу всієї сорери публічних закупівель, саме коли є суттєві зміни в системі. Це пов'язано 3 важливістю певних індикаторів саме ефективності публічних закупівель, які не завжди вимірюються економією на ціні, оскільки в країнах ЄС беруть до уваги витрати на товар протягом життєвого циклу, чого поки в Україні не дотримуються при проведенні тендерів.

Нова редакція Закону України «Про публічні закупівлі», яка почала діяти 3 19.04.2020 р., здебільшого базується на досвіді країн ЄС 3 їх проведення. Вона частково вирішила проблеми проведення тендерних закупівель в Україні, але деякі з проблем ще вимагають пошуку адекватних сьогоденню шляхів вирішення.

Складною проблемою донедавна було зростання кількості скарг, поданих до АМКУ [9, с. 8]. До Антимонопольного комітету України згідно листа від 01.02.2021 № 20-29/01-1561 як органу оскар- 
ження, у період з 01.01.2020 по 31.12.2020 надійшло 12675 скарг. 3 них до розгляду прийнято 11463 скарги.

За результатами розгляду скарг прийнято 24270 рішень, 3 них: 3808 рішень про відмову у задоволенні скарги, 6834 скарги задоволено повністю або частково, прийнято 1145 рішень про припинення розгляду скарг.

Частка договорів 3 іноземними учасниками в 2018 році становить 0,1\% (850 договорів) від загальної кількості та 9\% (59,1 млрд грн) від загальної суми договорів укладених 2018 року. Всього в публічних закупівлях в Україні прийняли участь учасники з понад 40 країн, найбільшу кількість договорів мають Чехія - 124, Німеччина - 85 , Китай - 70, Велика Британія - 65, Російська Федерація - 61 та США - 60. Крім того, найбільшими сумами договорів в звітному році відзначилась трійка лідерів - Китай з понад як 26,5 млрд. грн, Франція - 18,4 млрд. грн. та США - 2,2 млрд. грн.

Протягом 2019 року участь в публічних закупівлях України прийняли 48 іноземних країн. Частка договорів укладених з іноземними учасниками від загальної кількості становить - 0,05\%. Розподіл укладених договорів з іноземними учасниками за методами закупівель за 2018-2019 рр. відбувся таким чином (табл. 1) [7].

Таблиця 1

Розподіл укладених договорів з іноземними учасниками за методами закупівель за 2018-2019 роки

\begin{tabular}{|l|c|c|}
\hline \multirow{2}{*}{\multicolumn{1}{|c|}{ Тип методу закупівлі }} & \multicolumn{2}{c|}{$\begin{array}{c}\text { Кількість } \\
\text { договорів }\end{array}$} \\
\cline { 2 - 3 } & $\mathbf{2 0 1 8}$ & $\mathbf{2 0 1 9}$ \\
\hline $\begin{array}{l}\text { Процедура звітування } \\
\text { про укладений договір }\end{array}$ & 460 & 371 \\
\hline Переговорна процедура & 127 & 169 \\
\hline $\begin{array}{l}\text { Відкриті торги із публікацією } \\
\text { англійською мовою }\end{array}$ & 104 & 66 \\
\hline Допорогова закупівля & 92 & 17 \\
\hline Відкриті торги & 58 & 34 \\
\hline $\begin{array}{l}\text { Переговорна процедура } \\
\text { за нагальною потребою }\end{array}$ & 9 & 8 \\
\hline Всього & 850 & 665 \\
\hline
\end{tabular}

Найбільше договорів з іноземними учасниками укладені на закупівлю промислової техніки - 200, ділових послуг: юридичних, маркетингових, консультаційних, кадрових, поліграфрічних та охоронних - 154, транспортного обладнання та допоміжного приладдя до нього - 127 та гірничодобувного та будівельного обладнання - 108.

Впродовж 2020 року участь в публічних закупівлях України взяли 593 учасники з 43 країн світу. Частка договорів укладених 3 іноземними учасниками від загальної кількості склала - 0,02\% на суму 32 млрд. грн. Топ 5 країн за кількістю укладених договорів наведено в таблиці 2 [7].
Таблиця 2

Топ 5 країн за кількістю укладених договорів у 2020 році

\begin{tabular}{|l|c|}
\hline \multicolumn{1}{|c|}{ Країни учасники } & Кількість договорів \\
\hline Чехія & 71 \\
\hline Велика Британія & 70 \\
\hline Республіка Польща & 63 \\
\hline $\begin{array}{l}\text { Федеративна Республіка } \\
\text { Німеччина }\end{array}$ & 60 \\
\hline Швейцарська Конфедерація & 55 \\
\hline
\end{tabular}

Найчастіше договори були укладені під час закупівлі таких товарів, робіт та послуг:

1) з будівництва трубопроводів, ліній зв'язку та електропередач, шосе, доріг, аеродромів і залізничних доріг; вирівнювання поверхонь;

2) послуг 3 юридичного консультування та юридичного представництва;

3) обладнання для повітряних і космічних літальних апаратів, тренажери, симулятори та супутні деталі;

4) послуг з організації виставок, ярмарок і конгресів;

5) арматури трубопровідної: крани, вентилі, клапани та подібні пристрої.

Важливість посилення фрінансової відповідальності учасників публічних закупівель в Україні багато в чому пояснюються тим, що вони поки допускають суттєві зловживання при проведенні тендерів. Серед них [5, с. 7]:

1) поділ предмету публічної закупівлі на окремі лоти для уникнення проведення конкурсних торгів;

2) встановлення в документації на проведення тендерів дискримінаційних вимог щодо окремих учасників, що підриває конкурентні умови при їх проведенні.

На даний час діє Проект ЄС «Гармонізація системи державних закупівель України зі стандартами ЄС» спрямований на сприяння розвитку міцної та послідовної системи управління державними фрінансами шляхом створення всеосяжної та прозорої нормативно-правової бази державних закупівель, ефективної інституційної інфрраструктури державних закупівель, системи відповідальної та чесної державної влади щодо державних закупівель, а також розвитку системи державної допомоги в Україні [6].

Норми ЄC не дають простих відповідей на питання в сорері державних закупівель. Жодна країна не може сказати, що розробила ідеальне комплексне рішення, яке можна легко застосувати в інших країнах [8].

Врахуючи директив ЄС в Україні зможе сприяти:

1) вдосконалення умов для конкуренції на ринку державних контрактів в Україні в результаті підвищення рівня законності, відкритості процесу укладення контрактів; 
2) забезпеченню кращого співвідношення ціни та якості при виборі переможця тендеру на державні закупівлі;

3) скороченню випадків корупції при укладенні державних контрактів шляхом посилення цілісності та підзвітності $з$ боку українських органів державної влади;

4) покращенню системи управління державними фрінансами, у тому числі зменшенню надмірного витрачання державних коштів;

5) зміцненню позиції України на міжнародному рівні завдяки виконанню міжнародних зобов'язань;

6) підвищенню конкурентоспроможності і експортного потенціалу українських підприємств на міжнародних ринках.

Висновки 3 проведеного дослідження. Отже, введення в дію нової редакції Закону України «Про публічні закупівлі» в 2020 р. змогло суттєво підвищити їх ефрективність, але не в повній мірі знизило корупційні ризики при їх проведенні. Запровадження нових підходів щодо посилення відповідальності учасників тендерних закупівель згідно нової редакції Закону України «Про публічні закупівлі» вимагає аналізу їх ефрективності та своєчасного реагування на можливі проблеми. Це все дозволить добитися підвищення ефективності публічних закупівель в Україні та посилить фрінансову відповідальність їх учасників.

Основним із напрямів удосконалення публічних закупівель в Україні могло б стати щорічне підвищення їх нижнього порогу на рівень запланованої інсрляції. Потрібно наблизити механізм здійснення публічних закупівель в Україні до вимог $€ C$, що дозволить нашій країні в майбутньому ставити питання щодо вступу в цю організацію. Виходом з цієї ситуації могло б стати створення в Україні спільних підприємств, які б могли приймати участь у тендерних закупівлях у нашій країні, особливо в рамках децентралізації.

\section{БІБЛІОГРАФІЧНИЙ СПИСОК:}

1. Буряк Я.В. Основні аспекти здійснення державного регулювання у сорері публічних закупівель в Україні. Проблеми і перспективи розвитку. 2017. № 6. С. 55-59.

2. Державне регулювання закупівель в умовах реалізації адміністративної реформи. Івано-Франківськ, 2012. С. 82.
3. Длугопольський О.В. Теорія економіки державного сектору України : навч. посіб. Київ : «ВД «Професіінал», 2007. С. 592.

4. Карлін М.І., Кошкіна К.С. Здійснення публічних закупівель в Польщі: досвід для України. Економічний часопис СНУ. Луцьк : Вежа-Друк, 2019. С. 121-127.

5. Конащук Н.Е. Фінансовий контроль у сфері публічних закупівель. Автореф. дис. к.е.н. Київ. КНЕУ. 2019. C. 21.

6. Кравченко В.І. Про суспільні фрінанси України. Фінанси України. 2012. №12. С. 20-30.

7. Офріційний сайт Міністерства розвитку економіки, торгівлі та сільського господарства. URL: http://www.me.gov.ua/

8. Тропіна В.Б. До питання про публічні фрінанси. Фінанси України. 2009. № 12. С. 28-34.

9. Фефрелов О. Тотальне оскарження - стан. Дзеркало тижня. 2020. 19 липня. С. 8.

\section{REFERENCES:}

1. Buryak Ya.V. (2017) Osnovni aspekty zdijsnennja derzhavnogho reghuljuvannja u sferi publichnykh zakupivelj $\vee$ Ukrajini [The main aspects of state regulation in the field of public procurement in Ukraine]. Problemy i perspektyvy rozvytku, no. 6, pp. 55-59.

2. Ivano-Frankivsk (2012) Derzhavne reghuljuvannja zakupivelj v umovakh realizaciji administratyvnoji reformy [State regulation of procurement in the context of administrative reform]. Ivano-Frankivsk, p. 82.

3. Dlugopolsky O.V. (2007) Teoriia ekonomiky derzhavnoho sektoru Ukrainy [Theory of economics of the public sector of Ukraine]. Kyiv: VD Professional, p. 592.

4. Karlin M.I., Koshkina K.S. (2019) Zdijsnennja publichnykh zakupivelj v Poljshhi: dosvid dlja Ukrajiny [Realization of public purchases in Poland: experience for Ukraine]. SNU Economic Journal. Lutsk: Vezha-Druk, pp. 121-127.

5. Konashchuk N.E. (2019) Finansovyj kontrolj u sferi publichnykh zakupivelj [Financial control in the field of public procurement] (PhD Thesis), Kiev: KNEU.

6. Kravchenko V.I. (2012) Pro suspiljni finansy Ukrajiny [On public finances of Ukraine]. Finance of Ukraine, no. 12 , pp. 20-30.

7. Oficijnyj sajt Ministerstva rozvytku ekonomiky, torghivli ta siljsjkogho ghospodarstva [Official site of the Ministry of Economic Development, Trade and Agriculture]. Available at: http://www.me.gov.ua.

8. Tropina V. B. (2009) Do pytannja pro publichni finansy [On the question of public finances]. Finance of Ukraine, no. 12, pp. 28-34.

9. Fefelov O. (2020) Totaljne oskarzhennja - stan [Total appeal - condition]. Dzerkalo tyzhnja. 19 July, p. 8. 